\title{
Duodenal Fistula
}

National Cancer Institute

\section{Source}

National Cancer Institute. Duodenal Fistula. NCI Thesaurus. Code C78256.

An abnormal communication between the duodenum and another organ or cavity. 